\title{
Biological Aspects of Channa limbata (Cuvier, 1831) in Ta Bo - Huai Yai Wildlife Sanctuary, Phetchabun Province, Thailand \\ (Aspek Biologi Channa limbata (Cuvier, 1831) di Suaka Hidupan Liar Ta Bo - Huai Yai, Wilayah Phetchabun, Thailand)
}

\author{
KAN KHOOMSAB* \& SUWIT WANNASRI
}

\begin{abstract}
The biological aspects of Channa limbata were studied between November 2013 and October 2014. A total of 346 fish specimens, 185 male and 161 female, were collected from Ta Bo, Huai Yai Wildlife Sanctuary, Phetchabun Province, Thailand. Specimens range from $7.3-17.2 \mathrm{~cm}$ in length with body weight 8 - $31 \mathrm{~g}$; sex ratio between males and females was 1: 0.7. The length $(L)$, weight $(W)$ relationship for mixed sexes was $W=0.2064 L^{1.85}\left(R^{2}=0.90\right)$. Gonadosomatic indices for males and females were measured monthly and varied from $0.21-0.65 \%$ and $1.96-3.74 \%$, respectively. Condition factors for males and females ranged between $0.54-2.20$ and $0.58-2.72$, respectively, with fecundity range 956 to 4,652 eggs in females. Fecundity $(F)$ to weight relationship was $F=189.53 W^{0.59}\left(R^{2}=0.71\right)$ and fecundity to length relationship was $F=68.82 L^{1.15}\left(R^{2}=0.77\right)$. The ratio between the intestine length and total length was $1: 2$, indicating that $\mathrm{C}$. limbata was a carnivorous feeder. Analysis of the stomach contents gave $84 \%$ insects and $16 \%$ aquatic weed. These results can be applied to conserve efforts to prevent the extinction of $\mathrm{C}$. limbata in protected areas.
\end{abstract}

Keywords: Biological aspects; Channa limbata; fecundity; gonadosomatic index; length- weight relationship

\section{ABSTRAK}

Aspek biologi bagi Channa limbata telah dikaji antara November 2013 dan 2014 Oktober. Sejumlah 346 spesimen ikan, 185 jantan dan 161 betina telah diambil dari suaka hidupan liar Ta Bo - Huai Yai, wilayah Phetchabun, Thailand. Julat spesimen adalah daripada 7.3 - $17.2 \mathrm{~cm}$ panjang dengan berat badan 8 - $31 \mathrm{~g}$; nisbah jantina antara jantan dan betina adalah 1: 0.7. Hubungan panjang $(L)$, berat badan $(W)$ untuk jantina campuran adalah $W=0.2064 L^{1.85}\left(R^{2}=0.90\right)$. Indeks gonadosomatik bagi jantan dan betina telah dikira secara bulanan dan berbeza-beza masing-masing daripada $0.21-0.65 \%$ dan $1.96-3.74 \%$. Faktor keadaan bagi jantan dan betina adalah dalam lingkungan antara $0.54-2.20$ dan 0.58 - 2.72, masing-masing dengan julat kesuburan 956 untuk 4,652 telur betina. Kesuburan $(F)$ kepada hubungan berat adalah $F=189.53 W^{0.59}\left(R^{2}=0.71\right)$ dan kesuburan kepada hubungan panjang $F=68.82 L^{1.15}\left(R^{2}=0.77\right)$. Nisbah antara panjang usus dan jumlah panjang adalah 1:2 yang menunjukkan bahawa $\mathrm{C}$.limbata adalah merupakan pembekal karnivor. Analisis kandungan perut memberikan $84 \%$ serangga dan rumpai akuatik $16 \%$. Keputusan ini boleh digunakan untuk usaha pemuliharaan dalam mencegah kepupusan C. limbata di kawasan pemeliharaan.

Kata kunci: Aspek biologi; Channa limbata; hubungan panjang-berat; indeks gonadosomatik; kesuburan

\section{INTRODUCTION}

Snakeheads (family Channidae) are air-breathing freshwater fishes from two genera: Channa native to Asia, Malaysia and Indonesia and Parachanna that is endemic to tropical Africa. However, the taxonomy of Channidae is not universally agreed, with leading authorities on snakehead systematics currently recognizing 26 species of Channa and three species of Parachanna (Courtenay \& Williams 2004). The genus Channa is distributed from southeastern Iran and eastern Afghanistan eastward through Pakistan, India, southern Nepal, Bangladesh, Myanmar, Thailand, Laos, Malaysia, Sumatra, Indonesia, Vietnam, Korea and China and northward into Siberia (Courtenay \& Williams 2004; Goswami et al. 2006). Channa limbata is one of the smallest species in the family Channidae, commonly termed the red-tailed snakehead. It is considered rare as it is found only in shallow forest streams and waterfalls close to mountainous terrain in Thailand.

Knowledge of some quantitative aspects is important in studying fish biology. Length and weight are standard data used in fish programs to estimate growth rates (Cherif et al. 2008). Pauly (1993) studied the length-weight relationships (LWRs) of a fish to predict weight from length measurements made in the yield assessment. In addition, previous research concerning Channidae concluded that the length-weight and length-length relationships of $C$. diplogramma, C.marulius, C. striata, C. punctatus and C. punctata followed by allometric growth (Ali et al.2013; Datta et al. 2013; Kashyap et al. 2014). Hannifar et al. (2006) investigated length-weight relationships of Channa punctata from Western River in which the study showed no significant difference $(p>0.05)$ in the LWR as a function of sex. 
Furthermore, gonadosomatic index (GSI) and fecundity studies are useful for making total population estimates, population dynamics or productivity. GIS were studied in C.marulius and C. ghachua which peak value of GSI was observed only once in the month of indicating only one spawning period in C. marulius i.e. from June to August while C.punctatus, GSI reaches maximum in August (Ghanbahadur et al. 2013; Prasad et al. 2011; Tiwari et al. 2014). C. punctatus was the highest values of GSI of in rainy season (Kapil et al. 2011).

The former measures gonad mass relative to total body mass and is a good indicator of sexual maturity, while the latter denotes egg laying capacity and refers to the number of ripe eggs produced during one spawning season (Nandikeswari \& Anandan 2013). Accordingly, information on reproduction is useful for fishery management and conservation (El-Ganainy 2010; Hossain et al. 2015, 2012; Maithya et al. 2012; Njiru et al. 2006).

To date, there is still lack of evidences available regarding the biological aspects of C. limbata in Thailand to facilitate management and planning for a sustainable natural population. Therefore, this study investigated the length-weight relationships, sex ratios, gonadosomatic indices, condition factors, fecundity and stomach contents of $C$. limbata in the Ta Bo-Huai Yai Wildlife Sanctuary, Muang District, Phetchabun Province, Thailand. The results can be used as a basis for further research on breeding to promote conservation and sustainable natural population.

\section{MATERIALS AND METHODS}

\section{SAMPLING SITE}

Samples of $C$. limbata were collected from Ta Bo-Huai Yai Wildlife Sanctuary, Muang District, Phetchabun Province, Thailand $\left(16^{\circ} 22^{\prime} 42.2^{\prime \prime} \mathrm{N} 101^{\circ} 17^{\prime} 21.4\right.$ "E). This area is abundance with $C$. limbata.

\section{SAMPLING AND LABORATORY ANALYSIS}

C. limbata specimens were collected overnight (18.00 to 06.00 ) from streams 0.5 to $20 \mathrm{~m}$ wide and 6 to $25 \mathrm{~cm}$ depth once a month for 12 months from November 2013 to October 2014 using a five basket fish trap. The samples were stored in ice before transportation to the biological laboratory at the Faculty of Science and Technology, Phetchabun Rajabhat University. The number of fishes collected each month is listed in Table 2. A total of 346 C. limbata specimens including 185 males and 161 females were measured. Standard lengths, total lengths and body proportions were measured using a slide caliper (Mitutoyo blade type). Body weight was recorded on a digital balance (E-scale DYB-300). All samples were preserved in $10 \%$ formalin and the taxonomic study followed the method of Villéger et al. (2010).

\section{SEX RATIO}

The fish were dissected and the sex characteristics of males and females were determined by examining the gonads (Ramez 2005). Statistical calculations for the sex ratio were performed using the Chi-square test (Rosner 2011) under the assumption that the proportion of males and females was $1: 1$.

\section{LENGTH-WEIGHT RELATIONSHIP}

The $C$. limbata specimens were weighed with a precision balance at a resolution of $0.01 \mathrm{~g}$. Total lengths were measured by a ruler at resolution of $0.1 \mathrm{~cm}$ and the relationship between weight and total length was determined using the following formula from Jin et al. (2015):

$$
\mathrm{W}=\mathrm{a} \mathrm{L}^{\mathrm{b}}
$$

which was transformed into a logarithmic equation as:

$$
\log \mathrm{W}=\log \mathrm{a}+\mathrm{b} \log \mathrm{L}
$$

where $\mathrm{W}$ is the weight $(\mathrm{g})$; $\mathrm{L}$ is the length $(\mathrm{cm})$; and a and $\mathrm{b}$ are constants.

The log-transformed (2) is a linear regression model. After calculating the relationship equation and the coefficient of determination $\left(\mathrm{R}^{2}\right)$, further examination was conducted to determine whether the equation explained the fluctuations of the dependent variables (y-axis).

\section{GONADOSOMATIC INDEX}

The specimens were cleaned and weighed. The stomach of each fish was then cut out to weigh the seminal vesicle and the ovaries. The weights were used to calculate the GSI following the method of Gaikwad et al. (2009) as follows:

$$
\text { GSI }=\frac{\text { weight } \text { of reproductive organ }}{\text { fish weight }} \times 100
$$

Monthly means of the GSI were compared to observe changes and to estimate the time of year when the reproductive organs attained their highest development.

\section{CONDITION FACTOR}

Monthly data regarding the weights and lengths of the fishes were used to calculate the condition factor using the method of Jin et al. (2015) as follows:

$$
\mathrm{K}=100\left(\mathrm{~W} / \mathrm{L}^{3}\right)
$$

where $\mathrm{K}$ is the condition factor; $\mathrm{W}$ is the weight $(\mathrm{g})$; and $\mathrm{L}$ is the total length $(\mathrm{cm})$; the factor of 100 is used to bring $\mathrm{K}$ close to a value of one. 


\section{FECUNDITY-LENGTH AND WEIGHT RELATIONSHIP}

The lengths of female $C$. limbata that were ready to lay eggs or whose eggs were in the maturity stage according to Nikolsky (1963) were measured. Their ovaries were then weighed and the eggs randomly counted. To do this, all the eggs were weighed and approximately $10 \%$ of the ovaries were randomly weighed. The eggs that were randomly chosen for counting were cleaned and the egg tissues were cut off. The ovaries were then cut lengthwise, opened and soaked in Gilson's fluid $(100 \mathrm{~mL} 60 \%$ alcohol, $880 \mathrm{~mL}$ water, $15 \mathrm{~mL} 80 \%$ nitric acid, $18 \mathrm{~mL}$ glacial acetic acid and $20 \mathrm{~g}$ mercuric chloride). After soaking for over $24 \mathrm{~h}$, the bottle was agitated to separate the eggs and the fluid was drained off. The leftover tissues were then removed, water was added and the bottle was shaken well and left for sedimentation. The water and the soft parts of the eggs were then removed and the eggs were filtered and drained before counting. The data were used to calculate the relationship between the length and weight of the fishes and the fecundity, according to Agbugui (2013) as follows:

$$
\begin{aligned}
& F=a L^{b} \text { or } \log F=\log a+b \log L \\
& F=a W^{b} \text { or } \log F=\log a+b \log W
\end{aligned}
$$

where $\mathrm{F}$ is the number of eggs; $\mathrm{L}$ is the total length $(\mathrm{cm})$; $\mathrm{W}$ is the weight $(\mathrm{g})$; and $\mathrm{a}$ and $\mathrm{b}$ are constants.

\section{STOMACH CONTENTS}

Stomach contents were studied using the occurrence method (Hyslop 1980; Jamabo \& Maduako 2015), cutting them open to examine the undigested material. The samples were analyzed using a low-power microscope. This was a basic study that compiled and recorded the food groups by examining and categorizing the types of food found in the stomachs. The results were displayed as percentages.

$$
\text { Frequency of occurrence }=\frac{X}{Y} \times 100
$$

where $\mathrm{X}$ is the number of stomachs where each food item was present and $\mathrm{Y}$ is the total number of stomachs.

\section{RESULTS AND DISCUSSION}

\section{TAXONOMIC CHARACTERISTICS OF CHANNA LIMBATA}

The red-tailed snakehead, C. limbata, is a species of freshwater fish in the Channidae family. Its shape is similar to other species of fish in the family, but the red-tailed snakehead is rounder and bigger. The body color ranges from light brown to dark blue, with polka-dot patterns or dark spots. The stomach is a light color. The bases of the pectoral fins have patterns of four - six dark lines. The dorsal fin, the anal fin and the caudal fin are gray or bluish with orange or light edges.
The body color is pale and it is almost impossible to see any pattern, while the dorsal, anal and caudal fins are opalescent bluish green. The edge of the caudal fin has an orange stripe. Fish in this family have a slim cylindrical shape, protruding wide mouths, big eyes, canine teeth, large flat heads that appear round like a snake, round bodies, long dorsal and anal fins, rounded caudal fins, large pectoral fins, small pelvic fins and cycloid scales. Fish in the striped snakehead group have a respiratory suprabranchial organ that appears as a red narrow opening in the pharynx.

C. limbata has a long, cylindrical body with a large mouth and sharp teeth. The enlarged scales on top of the head with eyes located far forward are similar to the scale patterns and eye positions of snakes. The largest ever recorded snakehead was almost six feet long. C. limbata is the smallest species in the Channidae family and ranges from the south of China to Myanmar, Thailand, Laos, Malaysia and Indonesia (Amilhat \& Lorenzen 2005; Song et al. 2013; Ward-Campbell \& Beamish 2005; Wijeyaratne 1994). Adult $C$. limbata are only 15 to $20 \mathrm{~cm}$ in length. $C$. limbata is considered rare as it is found only in shallow forest streams and waterfalls close to mountainous terrain. Most of C. limbata are classified as C. gachua, which is a similar species found in India. However, in reality, these two fish types are quite different and subject to ongoing academic documentation and discussion. Morphological measurements of the average lengths of the sample specimens collected are shown in Table 1.

TABLE 1. Morphological measurements of average lengths of Channa limbata

\begin{tabular}{lc}
\hline Morphometric characteristics $(n=346)$ & $\begin{array}{c}\text { Average } \\
\text { length }(\mathrm{cm})\end{array}$ \\
\hline Body standard length & 10.97 \\
Body depth & 1.62 \\
Caudal peduncle minimal depth & 1.28 \\
Caudal fin depth & 1.12 \\
Caudal fin surface & 0.82 \\
Distance from insertion of pectoral fin to & 1.41 \\
$\quad$ bottom of body & 1.67 \\
Body depth at level of pectoral fin insertion & 1.90 \\
Pectoral fin length & 1.35 \\
Pectoral fin surface & 1.23 \\
Head depth along vertical axis of eye & 0.41 \\
Eye diameter & 0.96 \\
Distance from center of eye to bottom of head & 0.51 \\
Distance from top of mouth to bottom of head & 2.35 \\
$\quad$ along head depth axis (measured with & \\
electronic caliper) & \\
Mody width & \\
\hline Mouth depth & \\
\hline
\end{tabular}




\section{SEX RATIO}

Random catching of $C$. limbata during the year produced 346 fish in total, 185 males and 161 females (Table 2). The overall sex ratio of males to females was 1:0.7. Study of the sex ratio assumed that the number of males was equal to females $(1: 1)$ at a reliability level of $95 \%$ and the mean Chi-square value for the whole year was 0.34 with a mean significance of 0.64 . Therefore, the sex ratio of $C$. limbata equaled 1:1 in accordance with the assumption. It was impossible to clearly differentiate the males and females from their appearance and even during the spawning season changes in reproductive organs could not be easily observed unless the stomach was pressed lightly, causing the eggs to ooze out. The testis and ovaries were investigated by dissection. The results regarding the sex ratio agreed with other researchers who also found more males than females (Benghali et al. 2014).

\section{LENGTH-WEIGHT RELATIONSHIP}

Fish lengths varied between 7.3 and $17.2 \mathrm{~cm}$ and the weights varied between 8 and $31 \mathrm{~g}$. The average weight was $18.33 \pm 5.70 \mathrm{~g}$ and the average length was $10.97 \pm 1.89$ $\mathrm{cm}$. The analysis of the relationship is displayed by (8) and (9):

$$
\begin{aligned}
& \mathrm{W}=0.2064 \mathrm{~L}^{1.85} \\
& \log \mathrm{W}=1.85 \log \mathrm{L}-0.68\left(\mathrm{R}^{2}=0.84, n=346\right)
\end{aligned}
$$

$\mathrm{R}^{2}$ was 0.84 , indicating that the length-weight of $C$. limbata had a significant relationship (Figure 1).

When only the 185 male $C$. limbata were considered, the average weight was $17.94 \pm 0.51 \mathrm{~g}$ and the average length was $10.82 \pm 1.81 \mathrm{~cm}$. This relationship is displayed by (10) and (11):

$$
\mathrm{W}=0.2202 \mathrm{~L}^{1.83}
$$

$$
\log \mathrm{W}=2.72 \log \mathrm{L}-11.60\left(\mathrm{R}^{2}=0.80, n=185\right)
$$

$\mathrm{R}^{2}$ equaled 0.80 , indicating that the length-weight of male C. limbata had a significant relationship (Figure 2).

When only the 161 female C.limbata were considered, the average weight was $18.21 \pm 5.75 \mathrm{~g}$ and the average length was $11.09 \pm 1.89 \mathrm{~cm}$. This relationship is displayed by (12) and (13):

$$
\begin{aligned}
& \mathrm{W}=0.1854 \mathrm{~L}^{1.89} \\
& \log \mathrm{W}=1.89 \log \mathrm{L}-0.73\left(\mathrm{R}^{2}=0.84, \mathrm{n}=161\right)
\end{aligned}
$$

$\mathrm{R}^{2}$ equaled 0.84 , indicating that the length-weight of female C. limbata had a significant relationship (Figure 3).

The logarithmic regression equation for the lengthweight relationship of $C$. limbata was smaller than the cubic value $(b<3)$ for both males and females, indicating an allometric growth pattern. An allometric growth pattern was also found in $C$. diplogramma and $C$. marulius (Ali et al. 2013). Kashyap et al. (2014) recorded an overall isometric growth pattern $(\mathrm{b}=3.01)$ in $C$. punctatus from the Gomti River, India. The weight of $C$. punctatus was almost the cube of its length and showed negative allometric growth $(b<3)$ in males and positive allometric growth $(b>3)$ in females. Thus, females grew longer than the males. The length-weight relationship with regards to allometry is essential to understand the basic growth pattern of a species. Among the allometric relationships, the length-weight relationship (LWR) of fishes can indicate the species'status in an environment and characterize patterns of growth (Ali et al. 2013; Froese 2006).

\begin{tabular}{|c|c|c|c|c|c|c|c|}
\hline Month/ year & $\begin{array}{c}\text { Number of } \\
\text { males }\end{array}$ & $\begin{array}{l}\text { Number of } \\
\text { females }\end{array}$ & Total & $\begin{array}{l}\text { Expected } \\
\text { value }\end{array}$ & $\begin{array}{l}\text { Male:female } \\
\text { ratio }\end{array}$ & $\begin{array}{l}\text { Chi- } \\
\text { square }\end{array}$ & Sig. \\
\hline Nov 2013 & 9 & 7 & 16 & 8 & 1:0.7 & 0.25 & 0.61 \\
\hline Dec 2013 & 12 & 15 & 27 & 13.5 & $1: 0.8$ & 0.33 & 0.56 \\
\hline Jan 2014 & 21 & 15 & 36 & 18 & $1: 0.7$ & 1.00 & 0.31 \\
\hline Feb 2014 & 18 & 12 & 30 & 15 & 1:0.6 & 1.20 & 0.27 \\
\hline Mar 2014 & 10 & 7 & 17 & 8.5 & $1: 0.7$ & 0.52 & 0.46 \\
\hline Apr 2014 & 18 & 15 & 33 & 16.5 & 1:0.8 & 0.27 & 0.60 \\
\hline May 2014 & 16 & 15 & 31 & 15.5 & 1:0.9 & 0.03 & 0.85 \\
\hline Jun 2014 & 11 & 14 & 25 & 12.5 & 1:0.7 & 0.36 & 0.54 \\
\hline Jul 2014 & 6 & 8 & 14 & 7 & $1: 0.7$ & 0.00 & 1.00 \\
\hline Aug 2014 & 16 & 18 & 34 & 17 & $1: 0.8$ & 0.11 & 0.72 \\
\hline Sep 2014 & 25 & 18 & 43 & 21.5 & $1: 0.7$ & 0.00 & 0.92 \\
\hline Oct 2014 & 23 & 17 & 40 & 20 & $1: 0.7$ & 0.02 & 0.86 \\
\hline Total & 185 & 161 & 346 & & & & \\
\hline Mean average & & & & 13.1 & $1: 0.7$ & 0.34 & 0.64 \\
\hline
\end{tabular}

\section{ESTIMATION OF GONADOSOMATIC INDEX}

Study of the GSI of female $C$. limbata showed values between 1.96 and $3.74 \%$ increasing from June to October. For male $C$. limbata, GSI values were $0.21-0.65 \%$ (Figure

TABLE 2. Number and ratio of male and female Channa limbata collected monthly between November 2013 and October 2014 


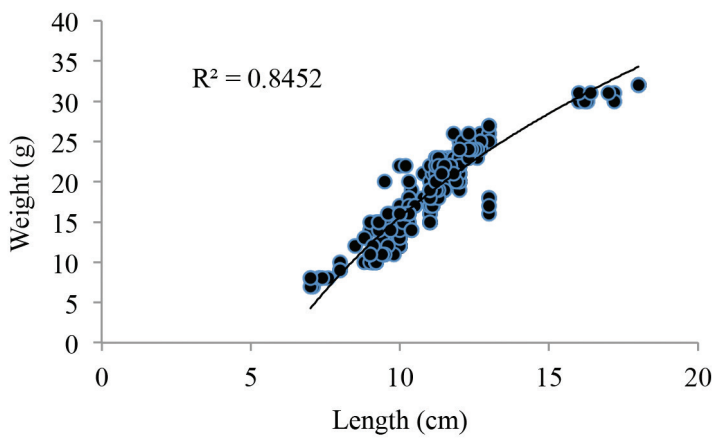

FIGURE 1. Length-weight relationship of Channa limbata with no gender discrimination

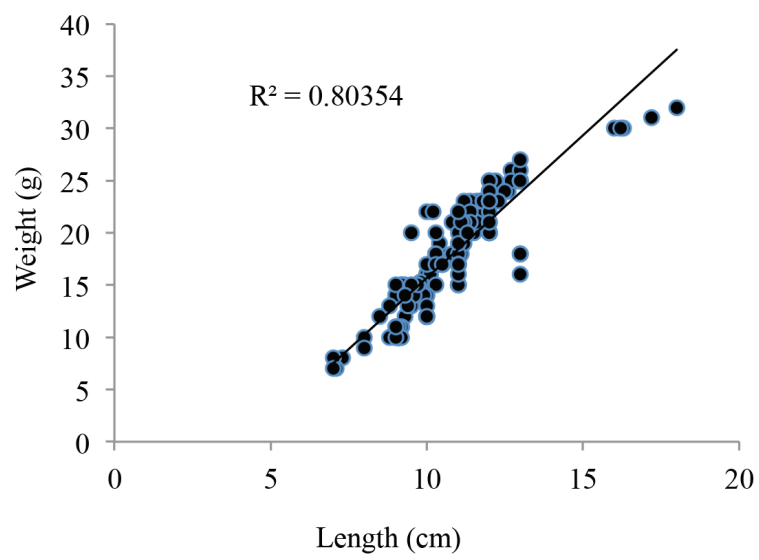

FIGURE 2. Length-weight relationship of male Channa limbata

4). These results agreed with the condition factors. GSI values were higher in females than males. Tiwari et al. (2014) reported a peak in GSI value for $C$. marulius in May, with a spawning period from June to August. Kapil et al. (2011) found that the GSI of C.punctatus was highest during the rainy season for both males and females. Mishra (1991) determined the highest GSI at 6.8 in June for C. gachua (Dwarf Snakehead). Several methods have been used to study the spawning season and the spawning

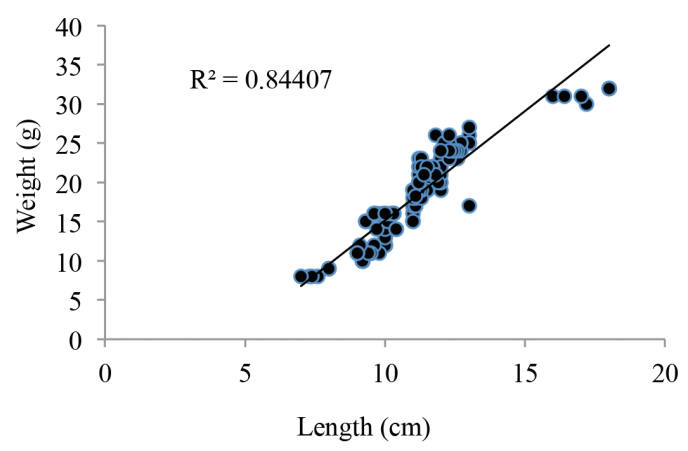

FIGURE 3. Length-weight relationship of female Channa limbata

grounds of aquatic animals. In tropical areas, the stage of development of the sex organs, the distribution of eggs and the survey of eggs and hatchlings assumes that when aquatic animals enter their spawning season, the weights of their sex organs will increase and peak before laying eggs. The results from this study showed that the monthly variation in GSI for $C$. limbata was highest during the rainy season. This concurs with the spawning theory of freshwater fishes in tropical areas, indicating that most freshwater fishes, including snakeheads, lay eggs during the rainy season.

\section{CONDITION FACTOR}

The condition factor of female $C$. limbata was between 0.58 and 2.72 and for males between 0.54 and 2.20 (Figure $5)$. Monthly variation in the condition factor indicated that the spawning season of $C$. limbata was during the rainy season (May - October). The results showed that the condition factor was higher in females than males. The condition factor is useful for the examination of aquatic animal health (Hossain et al. 2015). It gives an indication of food availability and the status of the reproductive systems, which reflects physical and biological circumstances. Fluctuations in the condition factor results from feeding conditions, parasitic infections and physiological factors.

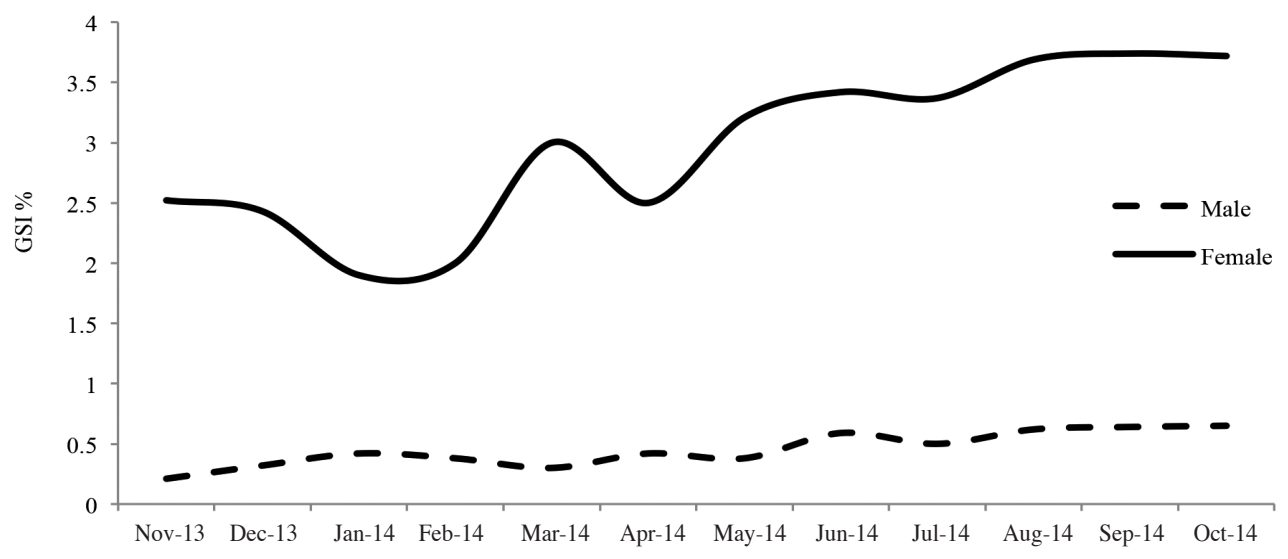

FIGURE 4. Gonadosomatic index of Channa limbata 


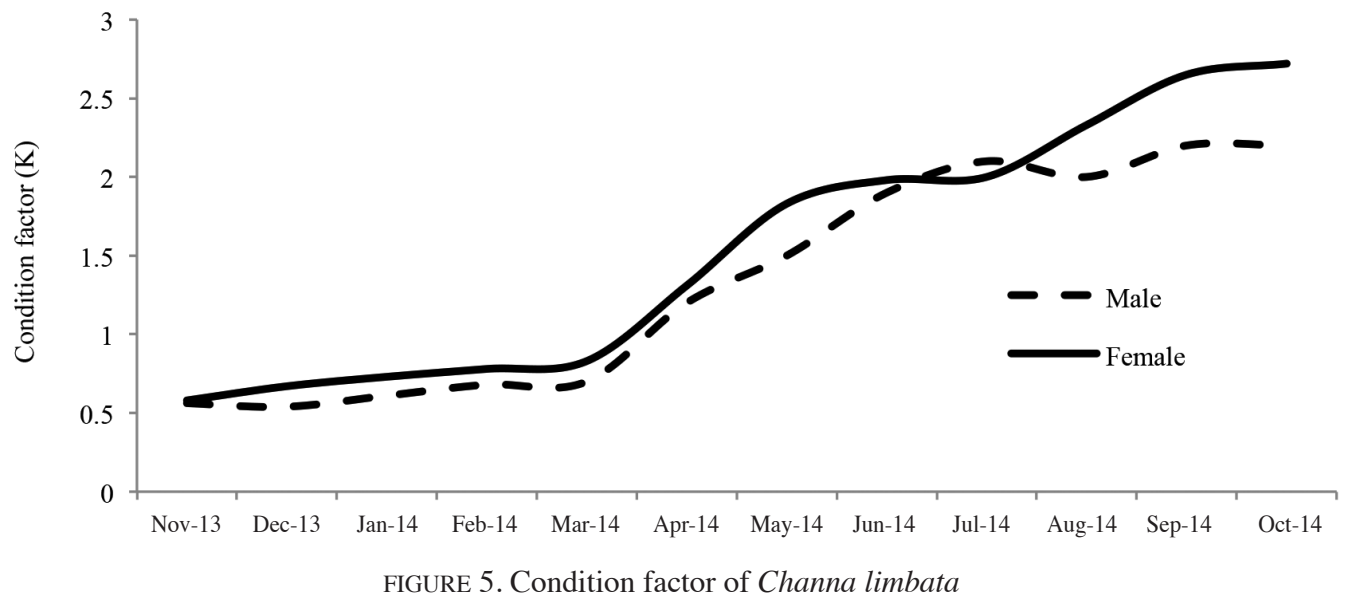

The condition factor also reflects changes in food reserves and is, therefore, an indicator of the general fish condition (Datta et al. 2013; Islam et al. 2013).

This study determined that the spawning season of $C$. limbata was during the rainy season, with development of the testis and eggs peaking in July and August 2014. It is possible to prevent extinction and develop C. limbata into a future economic species with artificial insemination of the eggs by the sperm of the fish. One problem which arose during the research was the difficulty in accurately differentiating the gender from the appearance alone. However, $C$. limbata is a rare species in its natural habitat of clean, running streams in mountain valleys and indepth research and study are necessary to prevent future extinction.

\section{FECUNDITY RELATIONSHIP}

For the female $C$. limbata, the average length was $11.09 \pm 1.89 \mathrm{~cm}$ and the average weight was $18.21 \pm 5.75 \mathrm{~g}$. The relationship between the length, weight, and number of eggs of female $C$. limbata was determined using (14) and (15):

$$
\begin{aligned}
& F=68.82 L^{1.15}\left(R^{2}=0.77, n=161\right) \\
& F=189.53 W^{0.59}\left(R^{2}=0.71, n=161\right)
\end{aligned}
$$

$\mathrm{R}^{2}$ values were calculated as 0.77 and 0.71 , indicating how the fecundity of $C$. limbata related to length and weight (Figures 6 and 7). The fecundity of the eggs refers to the number of ripe eggs or the eggs that are about to ripen, in the ovary before laying. Previous studies determined that the fecundity varied according to the size and weight of the fish. This explanation is usually expressed as a power function. The results showed 956 to 4,652 eggs in females. Mishra (1991) estimated that the fecundity varied between 2,539 and 7,194 in 15 mature specimens of C. gachua, ranging from 13.4 to $17.2 \mathrm{~cm}$ in length. Relationships between fecundity and length as well as fecundity and body weight were linear. However, the fecundity estimation

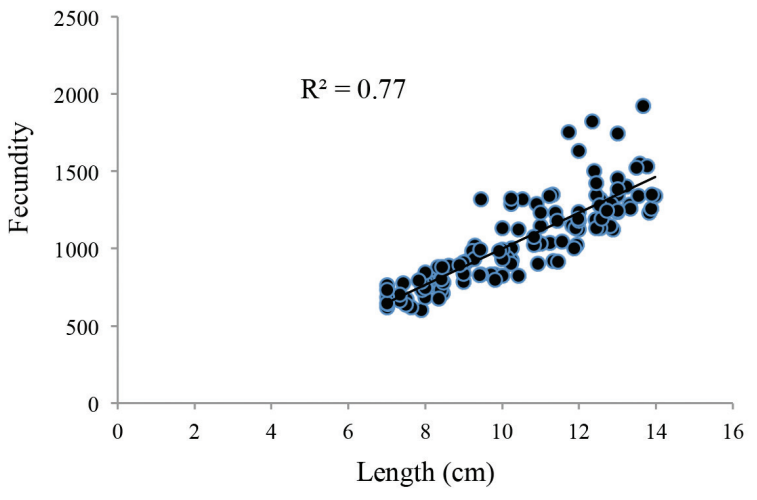

FIGURE 6. Relationship between fecundity and length

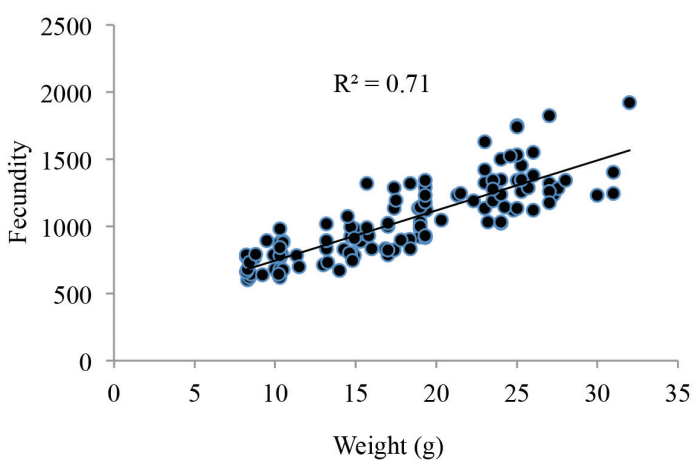

FIGURE 7. Relationship between fecundity and weight

must consider a variety of attributes, including size at first sexual maturity, duration of spawning season, daily spawning behavior and spawning fraction, when evaluating the commercial potential of fish stocks (El-Drawany 2013; Hossain et al. 2012). A relationship between length, weight, and fecundity for the Channidae family was reported by Gaikwad et al. (2009) for C. gachua, Islam et al. (2013) for C. striatus and Widodo et al. (2013) for C. gachua. Knowledge of fecundity is useful for the imposition of adequate regulations for the conservation of this threatened species (Hossain et al. 2012). Relative fecundity, as the number of eggs per unit weight, is commonly used as an 
index of fecundity. The fecundity of an individual female also varies according to many factors including age, size, species, food availability and season.

\section{STOMACH CONTENTS}

Eighty-four percent of the food found in C. limbata stomachs was insects and sixteen percent was small pieces of plant material. Therefore, it was concluded that C. limbata are carnivorous. The ratio between intestine length and total length was $1: 2$, and this also indicated that the fish is a carnivorous feeder. Carnivorous fishes generally have shorter intestines than their omnivorous and herbivorous cousins (Qin \& Fast 1996). The food items of snakeheads consist mainly of mouse, tadpole, fish, prawn, other crustaceans, terrestrial insects, detritus, smaller ephemeropterans, ipterans, hymenoptera, odonata, lepidoptera and some mosquito larvae (Bolaji et al. 2011; Lee \& Peter 1994; Ward-Campbell \& Beamish 2005). However, the gut contents only indicate what the fish has fed on recently. Accurate descriptions of fish diets and feeding habits are important to understand the trophic interactions in aquatic food webs. Fish diets represent an integration of many important ecological components that include behavior, condition, habitat use, energy intake and other inter/intraspecific interactions.

\section{CONCLUSION}

This study considered $C$. limbata, the smallest member of the Channidae family found in Thailand. Linear regression was used to determine the length-weight relationship. The results indicated an overall allometric growth pattern, with GSI values and the condition factor increasing during the rainy season and lowest in the winter and summer seasons. The breeding season from March to October agreed with the spawning theory that freshwater fishes in tropical areas, including snakeheads, lay eggs during the rainy season. The relationships between fecundity, total length, body weight and number of eggs were found to be significant. The results can be used to initiate breeding programs for C. limbata to protect this threatened and endangered Thai freshwater fish species.

\section{ACKNOWLEDGEMENTS}

This study was financially supported by the National Research Council of Thailand and the Research and Development Institute, Phetchabun Rajabhat University. We sincerely thank Ta Bo - Huai Yai Wildlife Sanctuary Officers for assistance with the collection of samples and their hospitality. The authors also thank Dr. Jolyon Dodgson for correcting the English text.

\section{REFERENCES}

Agbugui, M.O. 2013. The sex ratio, gonadosomatic index, stages of gonadal development and fecundity of the grunt, Pomadasys jubelini (Cuvier, 1830) in the New CalabarBonny River. Report and Opinion 5(11): 31-37.
Ali,A., Dahanukar, N. \& Raghavan, R. 2013. Length-weight and length-length relationship of three species of snakehead fish, Channa diplogramma, C. marulius and C. striata from the riverine reaches of Lake Vembanad, Kerala, India. Journal of Threatened Taxa 5(13): 4769-4773.

Amilhat, E. \& Lorenzen, K. 2005. Habitat use, migration pattern and population dynamics of chevron snakehead Channa striata in a rainfed rice farming landscape. Journal of Fish Biology 67(Suppl. B): 23-34.

Benghali, S.M.el.A., Mouffok, S., Kherraz, A. \& Boutiba, Z. 2014. Some aspects on the reproductive biology of greater forkbeard Phycis Blennoides (Brünnich, 1768) in western Algerian coasts (Osteichthyes, Gadidae). IJRRAS 19(3): 199-206.

Bolaji, B.B., Mfon, T.U. \& Di, U. 2011. Preliminary study on the aspects of the biology of snakehead fish Parachanna obscura (Gunther) in a Nigerian wetland. African Journal of Food, Agriculture, Nutrition and Development 11(2): 4708-4716.

Cherif, M., Zarrad, R., Gharbi, H., Missaoui, H. \& Jarboui, O. 2008. Length-weight relationships of 11 fish species from the Gulf of Tunis (SW Mediterranean Sea, Tunisia). PanAmerican Journal of Aquatic Sciences 3(1): 1-5.

Courtenay, W.R. \& Williams, J.D. 2004. Snakeheads (Pisces, Channidae) - A Biological Synopsis and Risk Assessment. Denver: U.S. Geological Survey.

Datta, S.N., Kaur, V.I., Dhawan, A. \& Jassal, G. 2013. Estimation of length-weight relationship and condition factor of spotted snakehead Channa punctata (Bloch) under different feeding regimes. SpringerPlus 2: 436.

El-Drawany, M.A. 2013. Some biological aspects of the Por's goatfish, (Family: Mullidae) from Tripoli coast of Libya. Egyptian Journal of Aquatic Research 39: 261-266.

El-Ganainy, A.A. 2010. Some biological aspects of the file fish Setphanolepis diaspros (Family: Monacanthidae) from the Gulf of Suez, Egypt. Researcher 2(10): 75-78.

Froese, R. 2006. Cube law, condition factor and weight-length relationships: History, meta- analysis and recommendations. Journal of Applied Ichthyology 22: 241-253. http://dx.doi. org/10.1111/j.1439-0426.2006.00805.x.

Gaikwad, M.V., More, V.R., Shingare, S.M., Hiwarale, D.K. \& Khillare, Y.K. 2009. Study on gonadosomatic and fecundity relationship in air-breathing fish Channa gachua (Ham.) from godavari near Aurangabad. African Journal of Basic \& Applied Science 1(5-6): 93-95.

Goswami, M.M., Borthakur, A. \& Pathak, J. 2006. Comparative biometry, habitat structure and distribution of four endemic snakedhead (TeleosteiI: Channidae) species of Assam, India. Journal Inland Fish. Soc. India 38(1): 1-8.

Hannifer, M.A., Nagaraja, M. \& Gopalakarisnan. 2006. Lengthweight relationship of Channa punctata (Bloch, 1793) from Western Ghats Rivers of Tamil Nadu. Journal of Applied Technology 22(5): 463-463.

Hossain, M.Y., Jahan, S., Jewel, M.A.S., Rahman, M.M., Khatun, M.M. \& Jasmine, S. 2015. Biological aspects of the critically endangered fish, Labeo boga in the Ganges River, northwestern Bangladesh. Sains Malaysiana 44(1): 31-40.

Hossain, M. Y., Rahman, M. M. \& Abdallah H, E. M. 2012. Relationships between body size, weight, condition and fecundity of the threatened fish Puntius ticto (Hamilton, 1822) in the Ganges River, northwestern Bangladesh. Sains Malaysiana 41(7): 803-814.

Hyslop, E.J. 1980. Stomach content analysis: A review of methods and their applications. Journal Fish Biology 17(4): 411-429. 
Islam, S.S., Shah, S. Md., Akter, R., Biswas, P., Sabbir, W. \& Bir, J. 2013. Some aspect of biology of snake head Channa striatus. Khulna University Studies 12(1\&2): 59-66.

Jamabo, N.A. \& Maduako, N.C. 2015. Food and feeding habits of Mugil cephalus (Linnaeus, 1758) in Elechi Creek, Niger Delta, Nigeria. International Journal of Fisheries and Aquaculture 7(3): 25-29.

Jin, S., Yan, X., Zhang, H. \& Fan, W. 2015. Weight-length relationships and Fulton's condition factors of skipjack tuna (Katsuwonus pelamis) in the western and Central Pacific Ocean. PeerJ. 3: e758. doi 10.7717/peerj.758.

Kapil, S., Kulkarni, K.M., Gijare, S.S. \& Tantarpale, V.T. 2011. Seasonal change of gonadosomatic index observed in the freshwater fish Channa punctatus. The Bioscan 6(4): 571573.

Kashyap, A., Awasthi, M. \& Serajuddin, M. 2014. Lengthweight and length-length relationship of freshwater murrel, Channa punctatus (Bloch, 1793) sampled from river Gomti in Lucknow region (Uttar Pradesh). World Journal of Fish and Marine Sciences 6(4): 336-339.

Lee, P.G. \& Peter, K.L.N. 1994. The systematic and ecology of snakedheads (Pisces: Channid) in Peninsular Malaysia and Singapore. Hydrobiologia 285: 59-74.

Maithya, J., Njiru, M., Okeyo-Owuor, J.B. \& Gichuki, J. 2012. Some aspects of the biology and life-history strategies of Oreochromis variabilis (Boulenger 1906) in the Lake Victoria basin. Lakes \& Reservoirs: Research and Management 17: 65-72.

Mishra, S.K. 1991. Reproductive biology of a freshwater teleost, Channa gachua (Ham): Proceedings of the National Symposium on New Horizons in Freshwater Aquaculture. CIFA Bhubaneswar, India. pp. 55-56.

Nandikeswari,R.\& Anandan, V.2013. Analysis on gonadosomatic index and fecundity of terapon puta from Nallavadu Coast Pondicherry. International Journal of Scientific and Research Publications 3(2): 1-4.

Nikolsky, G.V. 1963. The Ecology of Fishes. London and New York: Academic Press.

Njiru, M., Ojuok, J.E., Okeyo-Owuor, J.B., Muciri, M., Ntiba, M.J. \& Cowx, I.G. 2006. Some biological aspects and life history strategies of Nile tilapia Oreochromis niloticus (L.) in Lake Victoria, Kenya. African Journal of Ecology 44: 30-37.

Pauly, D. 1993. Linear regressions in fisheries research. Journal of the Fisheries Research Board of Canada 30: 409-434.

Qin, J.\& Fast, A.W. 1996. Size and feed dependent cannibalism with juvenile snakehead Channa striatus. Agriculture 144: 313-320.

Ramez,A.H. 2005. Some biological aspects of the Himri Barbel, Barbus luteus, in the intermediate reaches of the Euphrates River. Turkish Journal Zoology 29: 311-315.
Rosner, B. 2011. Fundamentals of Biostatistics. 7th ed. Boston: Brooks/Cole, Cengage Learning.

Song, L.M., Munian, K., Abd Rashid, Z. \& Bhassu, S. 2013. Characterisation of Asian snakehead murrel Channa striata (Channidae) in Malaysia: An insight into molecular data and morphological approach. The Scientific World Journal 2013: Article ID. 917506.

Tiwari, K., Singh, B.K., Singh, S. \& Tiwari, A. 2014. Study of gonadosomatic index of fresh water fish Channa marulius. International Journal of Scientific and Research Publications 4(5): $1-2$

Villéger, S., Miranda, J.R., Hernández, D.F. \& Mouillot, D. 2010. Contrasted changes in taxonomic and functional diversity of tropical fish communities after habitat degradation. Ecological Applications 20(6): 1512-1522.

Ward-Campbell, M.S. \& Beamish, F.W. 2005. Ontogenetic changes in morphology and diet in the snakehead, Channa limbata, a predatory fish in western Thailand. Environmental Biology of Fishes 72: 251-257.

Widodo, M.S., Marsoedi, Susilawati, T. \& Agung Permana, W.M 2013. Maturity level and somatic index of Gonado at Dwarf Snake-head (Channa gachua) during January to December 2009. Journal of Basic and Applied Scientific Research 3(3): 387-393.

Wijeyaratne, M.J.D. 1994. Some aspects of biology of the snakedhead, Ophicephalus striatus Bloch in Muthurajawela, a peaty swamp in Sri Lanka. Vidyodaya Journal of Science 5(1): 175-182.

Kan Khoomsab*

Biology Program

Faculty of Science and Technology

Phetchabun Rajabhat University, Phetchabun

Thailand

Suwit Wannasri

Education Science Program

Faculty of Science and Technology

Phetchabun Rajabhat University, Phetchabun

Thailand

*Corresponding author; email: topkan13@hotmail.com

Received: 26 January 2016

Accepted: 15 November 2016 